\title{
Trip Report United Arab Emirates
}

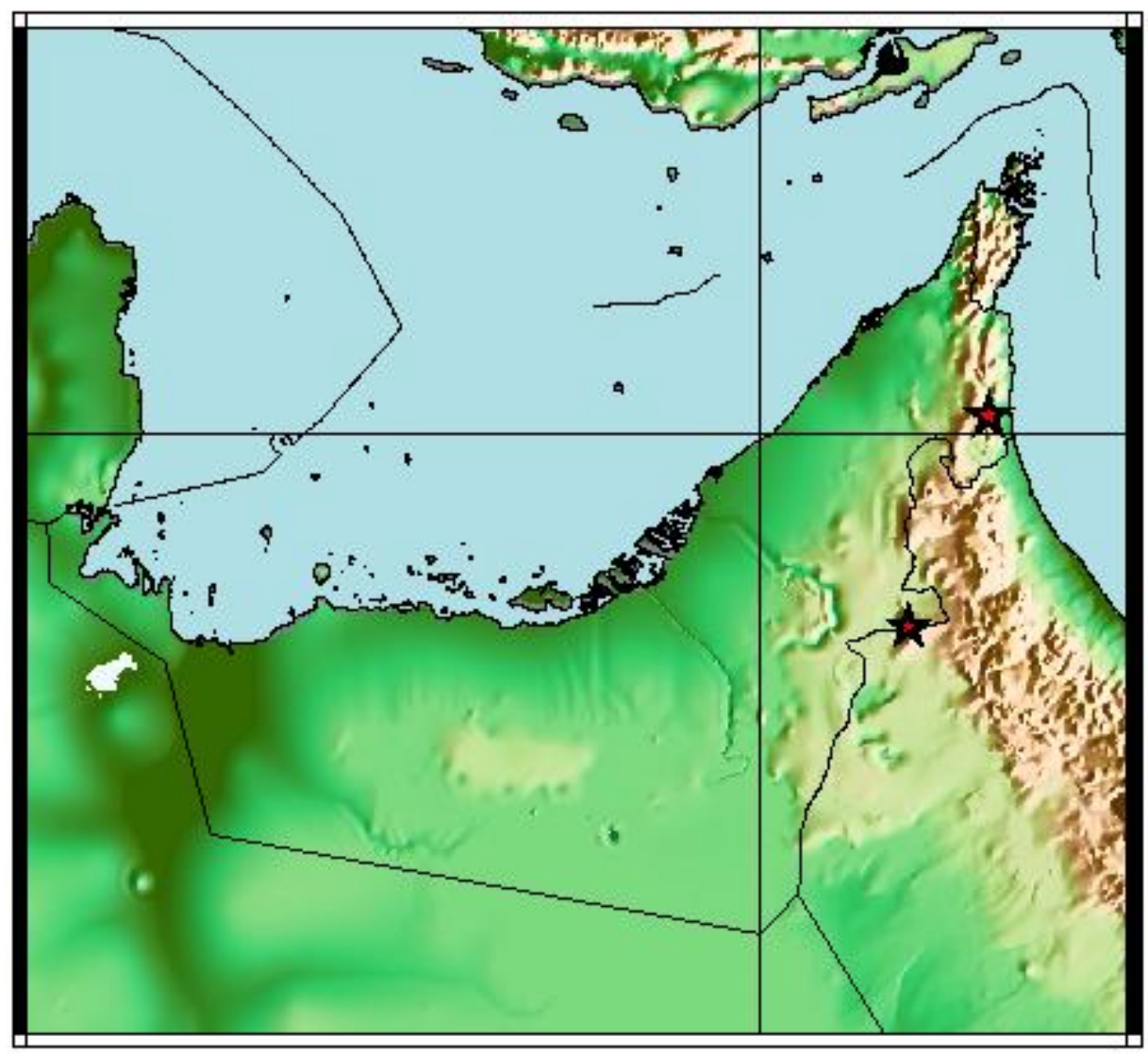

Keith Nakanishi

February 14, 2004 to February 27, 2004 Arthur Rodgers, Jr. February 12, 2004 to February 27, 2004

\section{Earth Science Division Energy and Environment Directorate Lawrence Livermore National Laboratory}

UCRL-TR-207089

This work was performed under the auspices of the U.S. Department of Energy by University of California, Lawrence Livermore National Laboratory under Contract W7405-Eng-48. 
This document was prepared as an account of work sponsored by an agency of the United States Government. Neither the United States Government nor the University of California nor any of their employees, makes any warranty, express or implied, or assumes any legal liability or responsibility for the accuracy, completeness, or usefulness of any information, apparatus, product, or process disclosed, or represents that its use would not infringe privately owned rights. Reference herein to any specific commercial product, process, or service by trade name, trademark, manufacturer, or otherwise, does not necessarily constitute or imply its endorsement, recommendation, or favoring by the United States Government or the University of California. The views and opinions of authors expressed herein do not necessarily state or reflect those of the United States Government or the University of California, and shall not be used for advertising or product endorsement purposes. 


\section{Summary}

Keith Nakanishi and Arthur Rodgers traveled to the United Arab Emirates in February, 2004 to continue an on-going technical collaboration with UAE University and to service the two temporary LLNL seismic stations. Nakanishi and Rodgers then participated in the Gulf Seismic Forum, which was organized by LLNL and sponsored by the University of Sharjah.

\section{Itinerary}

February 11, 2004

February 13, 2004

February 14, 2004

February 16, 2004

February 16-20, 2004

February 20-25, 2004

February 26, 2004

February 27, 2004
Rodgers travels San Francisco to Dubai (arrival 2/12/2004)

Rodgers travels Dubai to Kuwait Nakanishi travels San Francisco to Dubai (arrival 2/15/2004)

Rodgers travels Kuwait to Dubai

Rodgers and Nakanishi travel from Dubai to Al Ain, UAE

Al Ain (UAE University)

Sharjah (Gulf Seismic Forum)

Dubai, UAE

Nakanishi and Rodgers travel from Dubai to San

Francisco 


\section{Summary of meetings at UAE University, AI Ain, UAE}

Nakanishi and Rodgers visited UAE University in Al Ain from February 1620, 2004 to continue technical collaborations that started in October, 2002, when Nakanishi and Rodgers initially visited UAE University. Two temporary broadband seismic stations were installed in May, 2003, in collaboration with UAE University. The principal point of contact at UAEU is Dr. Fadhil Sadooni, chair of the Geology Department and the primary technical contact is Dr. AbdelRahman Fowler, of the Geology Department.

Nakanishi and Rodgers had an opportunity to visit with Dr. Joseph Hill, the new Dean of Sciences at UAEU. Hill is an American mathematician and recently retired from Auburn University. Nakanishi, Rodgers, Hill and Sadooni discussed the status of the LLNL temporary seismic stations as well the Gulf Seismic Forum. Sadooni expressed frustration that questions about earthquakes and seismicity were frequently directed to him by government officials and the press. This is an on-going issue and LLNL had previously suggested ways that UAEU could address these inquiries.

Hill expressed his disappointment that LLNL chose to team with Sharjah for the 2004 Gulf Seismic Forum. Sadooni further mentioned that the UAEU Vice-Chancellor was upset that LLNL did not choose to work with UAEU on the Forum. Hill wanted to know the reasons for this decision. Nakanishi explained that the intent of LLNL was to have UAEU and Sharjah cosponsor the Forum, however UAEU refused to team with Sharjah although Sharjah was willing to cosponsor the Forum with UAEU. LLNL was thus left to choose between either UAEU or Sharjah. Nakanishi told Hill that the deciding factor was the lack of any communications from the designated UAEU contact with LLNL in the months leading up to the Forum. Since it was crucial to start planning, LLNL decided to work with Sharjah. After Sadooni left the meeting, Hill told Nakanishi and Rodgers that LLNL's actions were understandable.

Hill and Sadooni said that having LLNL and UAEU work together and organize the 2005 Forum would help to mend relations. LLNL accepted UAEU's offer and agreed to work together for next Forum, planned for AI Ain, UAE in February, 2005. Sadooni assigned a different point of contact, Dr. Fowler, who has been very good in starting the planning process for the 2005 Forum.

Nakanishi and Dr. Amir Gabr worked on the computer systems at the UAEU Seismic Monitoring Laboratory installing and configuring the SeisAn and SAC software processing tools. The UAEU lab consists of two Dell Optiplex desktop computers, one running Windows XP and which is used to read the data from the field stations and to archive the data. The other Optiplex is used for data processing and the UAEU computer systems administrator installed RedHat Linux 9 on it so that SAC and SeisAn could be installed. Nakanishi was successful in completing the installation of Linux, however due to differences in 
configuration parameters, was not able to complete the installation of SAC and SeisAn. On his return to the US, Nakanishi was able to determine the configuration parameters needed and sent the installation directions for both SAC and SeisAn to Gabr.

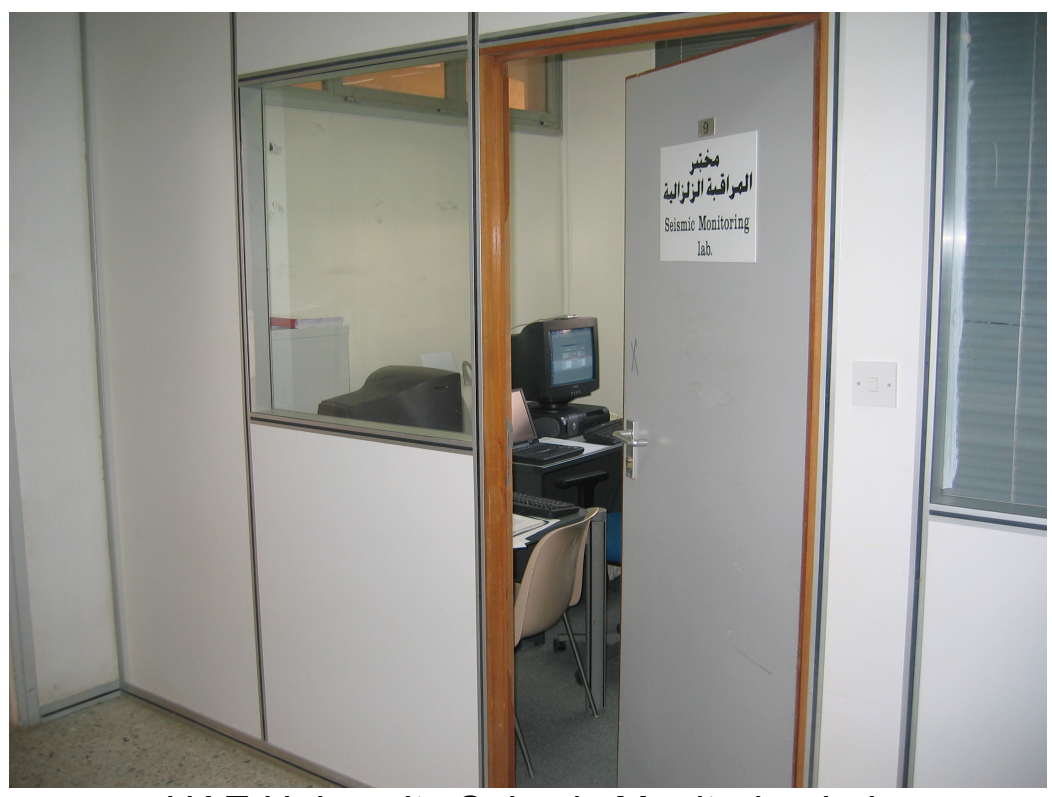

UAE University Seismic Monitoring Lab

Rodgers devoted nearly a week in an effort to address several problems with the seismic stations. Both stations (Mezyad, near Al Ain, and Al-Hayl, in Fujairah) exhibited spikes in the signal channel at 1 second intervals. Rodgers and Fowler visited both stations and first attempted to address this problem by moving the GPS clock cable away from the power cable from the solar cells. This was not successful in solving the problem of the spikes. On a subsequent visit, Rodgers and Fowler grounded the casing of the solar cells through a steel spike driven into the ground. Neither solution was found to eliminate the spikes and this problem remains unsolved.

A major problem that was identified by Fowler was that there was insufficient power from the solar cells at the Al-Hayl station to fully charge the batteries and operate the power supply for the station. Rodgers and Fowler went to the Al-Hayl station intending to install a solar cell bank to supplement the original cells. They found that in addition to insufficient power, the solar cells had been recently damaged by falling or thrown rocks. 


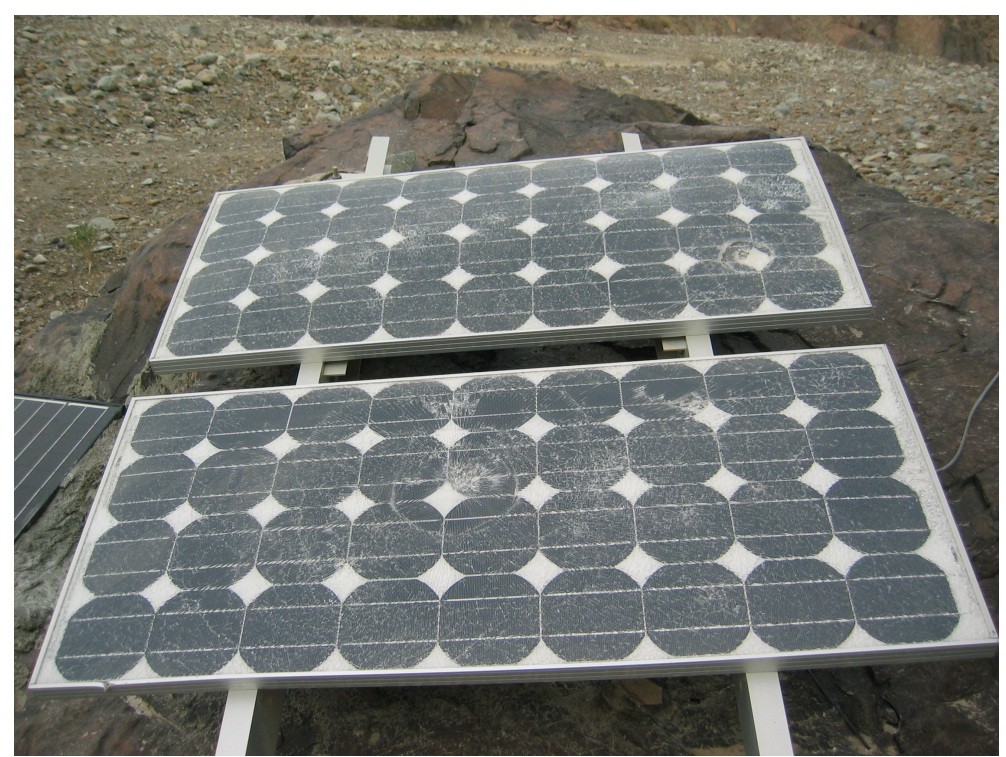

Damaged solar cells at Al Hayl station

Rodgers found that the damaged cells were producing power, although it was not known whether the power was sufficient to fully charge the batteries and operate the system. As planned, Rodgers and Fowler installed a second set of solar cells to supplement the original set. The system was given time to charge the batteries and see if the old and new sets of solar cells were sufficient to power the station.

With the exception of the annoying 1 second spikes, the Mezyad station was working well and there were no issues with vandalism, and there was sufficient power to operate the station.

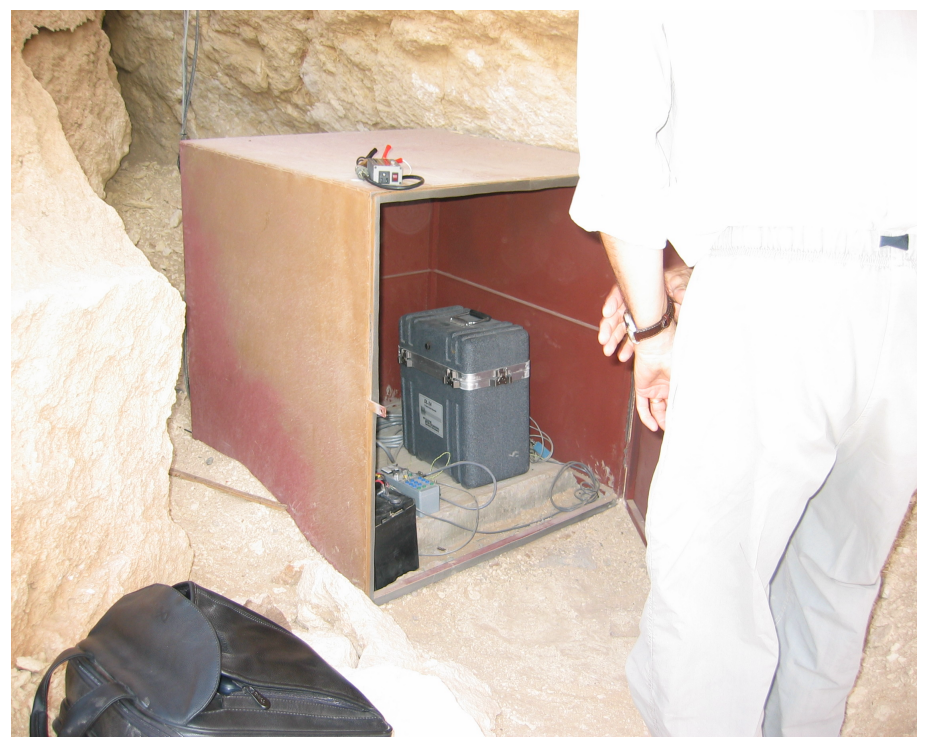

Mezyad seismic station 
Subsequent checking of the system and power at the Al-Hayl station indicated that there still was insufficient power produced by the solar cells to operate the station. Rodgers and Nakanishi decided that the combination of the damage to the solar cells, insufficient power even with the new solar cells working with the original cells, and difficulties in servicing the station due to distance from Al Ain dictated that the Al-Hayl station be dismantled and brought to Al Ain.

Rodgers installed the Al-Hayl seismic equipment in one of the Geology Department labs at Al Ain. The intent was to provide UAEU with means to address inquiries promptly regarding seismic activity in the region. Unfortunately, hardware problems and high natural noise levels made this option less than ideal. Problems with the data acquisition system also made it impossible to archive the data from the system at Al Ain.

Nakanishi and Rodgers left Al Ain for Sharjah and the Gulf Seismic Forum on February 20, 2004. Rodgers drove to Al Ain on both February 21 and 22 to complete the moving of the Al-Hayl station and setting the station up at UAEU. Nakanishi participated in the Forum field trip and preparations for the Forum. 


\section{Gulf Seismic Forum}

Lawrence Livermore National Laboratory, the U.S. Geological Survey and the Research and Studies Center of the University of Sharjah organized the first Gulf Seismic Forum that was held at the University of Sharjah, UAE from February 22-25, 2004. LLNL and USGS planned the scientific program while the University of Sharjah was responsible for the logistics for the Forum as well as arranging for the sponsors. There were over 90 registered participants from Canada, Iraq, Jordan, Kuwait, Oman, Saudi Arabia, South Africa, Switzerland, Turkey, the United Kingdom as well as from the UAE and the US. The Forum announcement is included in Appendix 1.

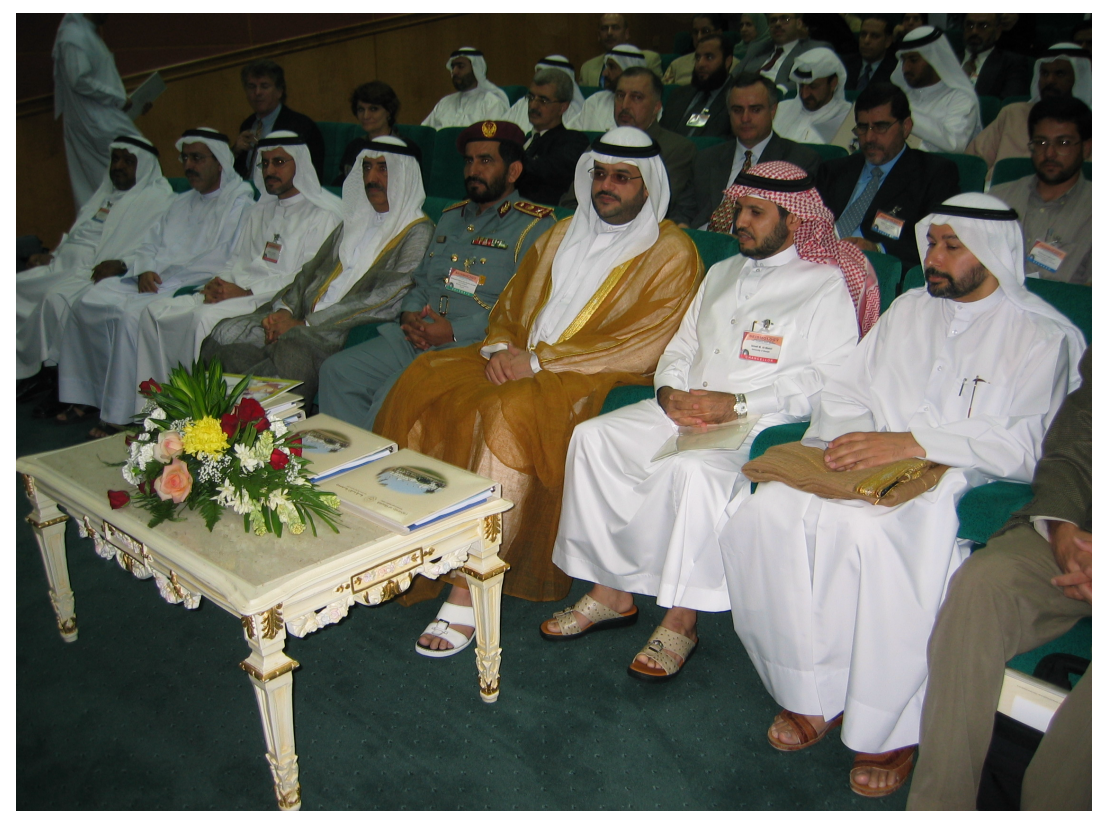

The Forum included a field trip to investigate the geology of the northern UAE especially in the region near the 2001 Masafi earthquake. Technical topics covered included seismology and seismicity of the Arabian Gulf region, earthquake hazards, hazard mitigation, seismic networks, and geophysics and tectonics of the region. The field trip agenda is included in Appendix 2.

Presentations at the Forum included surveys of data and seismic stations in the region, earthquake hazard assessments, seismicity studies as well as presentations on seismic equipment selection, software tools, and processing methods. There were discussions on earthquakes in the Gulf region, especially in the western Gulf and the impacts of large earthquakes in the eastern Gulf on the region.

Comments and discussions during the Forum covered several topics. There was a concern that hazards from earthquakes as well as seismology should be covered when talking about the Gulf region. In particular, there is a 
need to increase awareness of hazards and perhaps incorporating universities in addressing societal impact. There is also a need for a unified building code in the Gulf region with a uniform method of evaluating building methods.

Risk assessment could start with a seismic zonation map and a strategy for reducing earthquake risk perhaps in the short term in reinforcing existing buildings and in the longer term, establish building codes. In particular, emphasis should address critical structures such as hospitals, schools, and universities where there is high potential population density.

There was a concern expressed that there is a potential disconnect associated with the wishes of scientists and the implementation of a governmental policy. Although there were many suggestions regarding the problem and methods of addressing the earthquake risk in the Gulf region, it is unsure if the governmental agencies responsible heard the suggestions and know how to proceed.

The Forum was successful measured by the number of participants, the interest exhibited by the attendees. There were offers to host the Forum for the next three years, attesting to the success of the Forum in Sharjah and insuring sustainability of the effort. Two sets of documents were produced as a result of the Forum that will be forwarded to the UAE federal authorities. The first document (Appendix 3) makes a recommendation regarding the infrastructure needed in the UAE to address present and future needs in the area of earthquake monitoring and hazard mitigation. The second document (Appendix 4) recommends actions required by countries in the Gulf region to better monitor earthquakes and address earthquake hazard mitigation.

Dr. Alnajjar planned to send the recommendations to the UAE government through the Sharjah University administration, then to the Sharjah government and relayed to the UAE federal government. 


\section{Appendix 1}

Under The Patronage of

H. H. Sheikh Dr. Sultan Bin Mohammed Al-Qassimi

Member of The Supreme Council, Ruler of Sharjah,

Supreme President of The University of Sharjah

The Research \& Studies Center

At

The University of Sharjah

in collaboration with

The Directorate of Civil Defense - Ministry of Interior, Ministry of Public Works and Housing, Ministry of Communication,

Ministry of Petroleum \& Mineral Resources, And

United Nations Educational, Scientific, and Cultural Organization (UNESCO)

Announces an International Forum on

\section{"Seismology and Earthquakes in the Arabian Gulf Region"}

"Towards Cooperative Efforts in Seismology"

22 - 25 February 2004, Sharjah, U.A.E 
INTRODUCTION

Seismology is an international science, because seismic waves do not recognize borders and effects of damaging earthquakes are not restricted by political boundaries. Because of this, cooperation between countries is crucial in better defining the effects of earthquakes and also in determining the structure of the earth. Investigations of seismic waves will indicate the nature of the mechanism of the earthquake that generated the seismic signals, the location of the earthquake as well as physical properties of the earth, through which the waves pass. This information can be used to mitigate the effects of damaging earthquakes, better define the location of faults in the earth and recognize areas that are prone to damage from earthquakes.

To achieve the main objective of mitigating the effects of damaging earthquakes, we must combine an understanding of the natural phenomenon with the technological means of protecting people from harm. Our operations must necessarily be influenced by local conditions, both in relation to the natural hazard and in respect of the resources, which each community can deploy in its own defence.

Earthquake hazards are related to soil conditions, geological structure and tectonic activity, which must be studied on a regional basis. A regional authority may well extend across several national frontiers, and frequently is in need of data from other parts of the world. Eventually, one comes to realize that the structure is indivisible, and that organizations at all levels must co-operate within a world-wide pattern.

It is a goal of this Forum to initiate a Arabian Gulf region-wide cooperation, which can address common technical issues in seismology which will lead to a better understanding of the earthquake process, seismicity, and hazard mitigation.

\section{OBJECTIVES}

1. To improve the ability to regionally monitor and define seismicity, to coordinate and integrate resources to facilitate region-wide seismic cooperation and to improve the state of technology in the region.

2. To provide information on seismic stations and networks in the Arabian Gulf region.

3. To better define seismic risk in the region.

4. To provide seismologists information on seismic processing and analysis tools.

\section{FORUM TOPICS}

- Arabian Gulf regional tectonics, seismicity and geology

- Seismic research, hazard assessment, and applications

- Seismic observatories in the region

- Seismic processing software and analysis tools and techniques 


\section{Tentative Forum Program}

Sunday, January 22, 2004

\begin{tabular}{|l|l|}
\hline 07:00 PM - 09:00 PM & Forum Reception \\
\hline
\end{tabular}

Monday, January 23, 2004

\begin{tabular}{l|l} 
09:00 AM - 05:00 PM & Field trip
\end{tabular}

Tuesday, January 24, 2004

\begin{tabular}{|l|l|}
\hline 09:00 AM - 10:00 AM & Registration \\
\hline 10:00 AM - 11:00 AM & Opening Ceremony \\
\hline 11:00 AM - 11:30 AM & Coffee break \\
\hline 11:30 AM - 11:50 AM & $\begin{array}{l}\text { Keynote address on Seismology, Tectonics and } \\
\text { Structure of the Arabian Peninsula and Gulf Region - } \\
\text { Dr. Abdullah Al- Amri }\end{array}$ \\
\hline 11:50 AM - 12:10 PM & $\begin{array}{l}\text { National Seismic Studies and Earthquake Monitoring } \\
\text { Stations in UAE: Status and Prospects - } \\
\text { Prof. Azm S. Al-Homoud }\end{array}$ \\
\hline 12:10 PM - 12:30 PM & $\begin{array}{l}\text { The March 11, 2002 Masafi, UAE Earthquake - } \\
\text { Dr. Arthur Rodgers }\end{array}$ \\
\hline 12:30 PM - 01:30 PM & Lunch \\
\hline 01:30 PM - 03:30 PM & Getting the right seismic system \\
\hline 03:30 PM - 04:00 PM & Coffee break \\
\hline 04:00 PM - 05:30 PM & Contributed papers \\
\hline
\end{tabular}

Wednesday, January 25, 2004

\begin{tabular}{|c|c|}
\hline 09:00 AM - 11:00 AM & $\begin{array}{l}\text { Available Resources, Computer Operating Systems and } \\
\text { Softwares for Seismic Research - Dr. Keith Nakanishi } \\
\text { and Mr. Abdel Qader Fandi Abdullah }\end{array}$ \\
\hline 11:00 AM - 11:30 AM & Coffee break \\
\hline 11:30 AM - 12:30 PM & $\begin{array}{r}\text { Available Resources, Computer Operating Systems and } \\
\text { Softwares for Seismic Research - Dr. Keith Nakanishi } \\
\text { and Mr. Abdel Qader Fandi Abdullah }\end{array}$ \\
\hline 12:30 PM - 01:30 PM & Lunch \\
\hline 01:30 PM - 04:00 PM & Contributed papers \\
\hline 04:00 PM - 04:30 PM & Coffee break \\
\hline 04:30 PM - 05:30 PM & Round Table Discussion - Future Directions \\
\hline 05:30 PM & Closing of the Forum \\
\hline & $\begin{array}{l}\text { Research and Studies Center } \\
\text { University of Sharjah } \\
\text { PO Box } 27272 \text { Sharjah, } \\
\text { United Arab Emirates } \\
\text { l. No.: +971-6-5050550/ } 5050569 \\
\text { Fax No.: +971-6-5050552 } \\
\text { Email: research-1@sharjah.ac.ae }\end{array}$ \\
\hline
\end{tabular}




\section{Appendix 2 \\ Itinerary for the Gulf Seismic Forum Field Trip 2004}

Excursion Leader: Dr. Abdel-Rahman Fowler

Areas to be visited: Wadi Ham and Wadi Shimal fault zones and associated features (Masafi-Fujairah-Dibba)

\subsection{Leave Holiday Inn Hotel Sharjah}

9.40 Tension-fractured cemented older alluvium just south of Wadi Dafta town.

There are also good examples of small travertine terraces and a travertine pond buried within the old alluvium. Travertine is deposited from warm springs deposits and is a good indicator of extensional neotectonism in the area.

10.20 Exposure of $\mathrm{N}-\mathrm{S}$ trending strike slip fault splaying off the Wadi Ham Fault. Well exposed fault striations pitch 15 degrees south. This fault separates metamorphic sole rocks from ophiolitic metagabbros and is associated with E-W tensional faults and fractures. One hundred metres farther south are sulphide deposits also developed along N-S striking tensional faults. These indicate significant hydrothermal activity along these fracture systems.

11.40 Dip-slip striations on N-S trending faults in metagabbro south of Bulaydah.

A totally different slip direction developed also on $\mathrm{N}-\mathrm{S}$ faults splaying off the Wadi Ham fault indicate complex reuse of existing fracture systems. Fault bounded blocks of ophiolite along Wadi Ham may be seen at this location.

12 pm (optional) Two stages of alluvial deposition.

The first includes rather angular cobble sized gravels partially cemented lying directly on bedrock. The second is a thicker sequence of unconsolidated more rounded boulder sediments. The second stage alluvium has intensely oxidized varnished gravels at its top.

12.20 Al-Hayl seismic recording station. Inspection of the seismic recording instruments currently operating from the United Arab Emirates University in collaboration with Lawrence Livermore Laboratories California.

1.10 (returning $\mathrm{N}$ towards Dibba) Residuals of uplifted alluvium north of Wadi Dafta. These lie about 5 metres above the level of the main alluvial fill of Wadi Ham valley. The alluvium is preserved on top of faulted basement blocks.

1.50 Wadi Shimal lookout. A spectacular view of Wadi Shimal - a normal fault with some transcurrent component. Deeply dissected alluvial gravels are seen. Absence of any faulting or fissuring of the alluvium in this valley suggests inactivity for this fault system in recent times.

2.30 Arrive Khor Fakkan for lunch. Leave 4.00.

6.00 Arrive Holiday Hotel, Sharjah. 
Recommendations from the Delegates of the International Forum on

"Seismology and Earthquakes in the Arabian Gulf Region"

Held at the University of Sharjah

22-25 February 2004

Research and Studies Center

University of Sharjah 


\section{Table of Content}

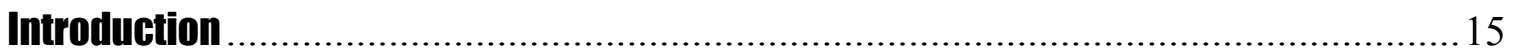

Seismological Activities in Region and the United Arah Emirates .............................. 16

Recommendations for the United Arab Emirates .................................................. 16

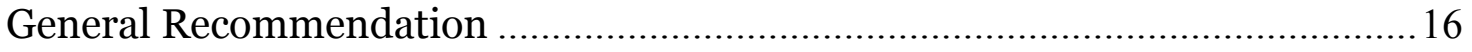

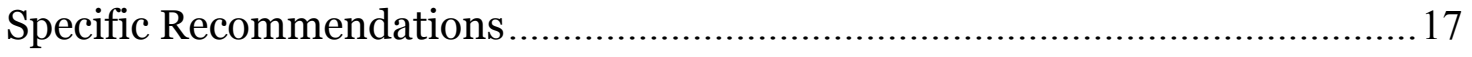

Short-Term Recommendations..................................................... 17

Long-Term Recommendations....................................................... 18

Recommendations for the Region, Especially the Arabian Gulf Region .......................19 


\title{
Recommendations from the Delegates of the International Forum on "Seismology and Earthquakes in the Arabian Gulf Region"
}

\author{
Held at the University of Sharjah
}

22-25 February 2004

\section{Introduction}

The University of Sharjah held during the period 22-25 February 2004 an International Forum titled "Seismology and Earthquakes in the Arabian Gulf Region". The meeting was held under the patronage of H. H. Sheikh Dr. Sultan bin Mohammed Al-Qassimi, Member of the Supreme Council, Ruler of Sharjah, The Supreme President of the University of Sharjah. The Forum was organized in collaboration with the Directorate of Civil Defense (Ministry of Interior), the Ministry of Public Works and Housing, the Ministry of Communication, the Ministry of Petroleum and Mineral Resources and the United Nations Educational, Scientific and Cultural Organization (UNESCO). International experts in seismology, seismic hazard assessment and earthquake engineering from Arab countries, particularly from the Arabian Gulf, Europe and the United States attended this meeting.

The Forum was opened by H.H. Sheikh Sultan Bin Muhammad Bin Sultan Al-Qassimi, Crown Prince, Deputy Ruler, and Chairman of the Executive Council. The Opening ceremony was attended by more than 120 delegates from all around the world, particularly representatives of Federal and local authorities, and expert scientists and engineers.

Two committees were formed to draft recommendations for discussion among the entire delegation. The committees involved representatives of the Ministries that sponsored the Forum and experts. One of the committees drafted recommendations for a national activity in seismology and the other discussed cooperation between seismological institutions in the region. The recommendations were developed into two parts:

1) Recommendations for the United Arab Emirates; and

2) Recommendations for the Region, especially the Arabian Gulf Region. 


\section{Seismological Activities in Region and the United Arab Emirates}

Earthquakes are not common in the United Arab Emirates and the Arabian Peninsula but are common in the regions surrounding the Arabian Gulf. Earthquakes are most common in the Zagros Mountains of Iran, however recently the northern Emirates earthquake swarm of 2002 alerted residents of the UAE to the consequences of earthquakes. Many small earthquakes, too small to be felt, could be occurring that would provide valuable information on seismic hazard if they were recorded by monitoring instruments. Institutions in the region operate several networks of seismic stations. These institutions contribute to the global effort to detect and locate earthquakes, as well as perform research on seismic hazard and building design and earthquake engineering.

The earthquake swarm in the northern Emirates in 2002 was widely felt and alerted the population of seismic hazard. However, information on these events and their risk to the UAE cannot be fully assessed because the limited availability of seismic stations deployed during the events. Without earthquake ground motion data from nearby stations $(0-100 \mathrm{~km})$, seismologists must rely on distant recordings of events. As a result only large infrequent events can be studied. Furthermore, without data seismologists and earthquake engineers cannot inform federal authorities of ground motion potential and the risks to buildings, homes, bridges, highways, industrial facilities, ports and other infrastructure.

\section{Recommendations for the United Arab Emirates}

\section{General Recommendation}

Based on the presentations and discussion that took place during the forum, the following important general recommendation was formulated:

The scientists and other delegates of the Forum and members of this committee agree that earthquakes pose a risk to the Arabian 
Gulf region. While the vulnerability to earthquake risk is lower within the Arabian Peninsula and the UAE compared with the surrounding regions, the risk is still worthy of careful consideration. Earthquakes pose risks such as to damage to homes, buildings and infrastructure as well as landslides, tsumanis and scheiche. These hazards must be assessed without delay in order to mitigate the consequences of earthquake damage including the loss of life. Finally, public awareness of earthquakes hazards and safety must be developed.

\section{Specific Recommendations}

Following discussions and taking into considerations the various views expressed during the sessions of the Forum, the Committee agreed to develop the recommendations into two categories:

1) Short-Term Recommendations; and

2) Long-Term Recommendations.

\section{Short-Term Recommendations}

1) A National Committee representing all concerned Ministries, authorities and research organizations on Earthquake Study and Hazard Assessment should be formed. This committee should be an independent organization having broad authority to develop a plan for the study of earthquakes and recommend design criteria for new construction. The committee should report to a high Authority to be decided by the Council of Ministers.

2) The Committee should collect all available information and summarize them into a preliminary seismic zonation and design criteria (building code) to be recommended for new construction. These criteria can be revised as more information is gathered and analysis is performed.

3) The Committee should solicit a preliminary evaluation of existing buildings and infrastructure and their susceptibility to earthquake damage.

4) The Committee should review emergency response preparedness of the UAE and make appropriate recommendations accordingly. 


\section{Long-Term Recommendations}

1) A National Earthquake Center be established to have federal authority to monitor and study earthquakes and provide policy makers with meaningful information on seismic hazard. The Center will advice and inform competent authorities on laws and legislation regarding earthquake hazard mitigation and emergency response. This Center will report to the Council of Ministers and will be overseen by the National Committee with representation from the various concerned Ministries and Federal and Local Authorities and organizations. This Center will have two arms:

a. Operational Division responsible for the operating national seismic network, reporting of earthquakes, and immediate communication of seismic activity to the concerned authorities.

b. A Research Division responsible for setting up research priorities and coordinating research activities within the UAE such as optimizing seismic networks performance, identification of seismic hazard, developing building codes and design criteria, and assessing existing infrastructure. The Center will coordinate earthquake studies with the regional and global institutions. In addition, the Division will promote education and awareness of earthquake activities, hazards and appropriate preparations.

2) This National Center must have:

a. Independent Federal Funding;

b. A mandate to have authority for earthquake science in the UAE;

c. Adequate staffing, including scientists, engineers, computer and electronic technicians.

3) A United Arab Emirates Seismic Network (UAESN) should be established to record seismic motions and 
define seismically active areas of the UAE. The National Center will define the specifications of and operate the UAESN, as well as perform research in earthquake studies and engineering.

4) The National Center should review existing national emergency plans and develop a mechanism for periodic review and update in addition to issuing recommendations specific to earthquake preparedness.

\section{Recommendations for the Region, Especially the Arabian Gulf Region}

In order to address the potential of better coordination between seismic networks in the Arabian Plate region, a committee was formed to examine the possible benefit of such coordination and the steps that would be needed to accomplish this. The committee agreed on the following:

1. The committee agreed that coordinating and utilizing data from all networks in the region is essential for improved assessment of seismic hazards, better location of earthquakes, and for investigating the tectonics of the region.

2. The committee agreed that periodic meetings of network operators is needed to discuss results of processing data from the various networks and possibly to process data from geophysically interesting events. The meeting interval should be nominally one year.

3. The committee agreed that at the very least, the combined data from the networks should require rapid exchange of data between seismic observatories. The data could be exchanges of bulletins, or exchange of parameter information, or exchange of seismic waveforms.

4. The committee noted that the inclusion and participation of Iranian seismic observatories is essential to the success of this coordination. 
5. The committee noted that inclusion of data from Qatar is necessary, and that seismic networks in Bahrain and the UAE are needed to complete regional coverage.

6. The committee feels strongly that an effort to equalize technical capacity and capabilities in the region is needed and assistance provided to those networks and observatories needing such assistance.

7. The committee feels that the preferred method of data exchange is through email and, when high bandwidth data is exchanged, such as waveforms that other protocols be used, such as (FTP).

8. The committee recommends that the regional network be initiated in stages. The first stage would be done immediately, with exchange of parameter data through the internet. The data exchange would then be extended to exchange of seismograms for selected events. In the first stages, each observatory would be responsible for their own regional bulletin. In the next stage, a virtual center would be constructed which would include advanced computational capability, network processing and bulletin production. In the final and most ambitious stage, a network data center could be established that would receive all data from earthquakes in the region, produce a bulletin, and archive the data.

9. The committee strongly feels that an official sanction for regional seismic exchange is needed. The committee believes that the recommendation for regional seismic corporation be recognized as a result of the workshop and that a letter to this effect be sent to all home organizations.

10. The committee feels that it is important that the governments of each country is informed about the importance of seismic networks and the role that the national observatories perform.

11. Finally, the committee feels that an evaluation of facilities is needed and capabilities be assessed and to determine if training is required for all involved countries. 


\section{Appendix 4}

\section{Recommendations for the Region \\ Coordination of data from seismic networks in the Arabian Plate region}

In order to address the potential of better coordination between seismic networks in the Arabian Plate region, a committee was formed to examine the possible benefit of such coordination and the steps that would be needed to accomplish this. The committee agreed on the following:

1. The committee agreed that coordinating and utilizing data from all networks in the region is essential for improved assessment of seismic hazards, better location of earthquakes, and for investigating the tectonics of the region.

2. The committee agreed that periodic meetings of network operators is needed to discuss results of processing data from the various networks and possibly to process data from geophysically interesting events. The meeting interval should be nominally one year.

3. The committee agreed that at the very least, the combined data from the networks should require rapid exchange of data between seismic observatories. The data could be exchanges of bulletins, or exchange of parameter information, or exchange of seismic waveforms.

4. The committee noted that the inclusion and participation of Iranian seismic observatories is essential to the success of this coordination.

5. The committee noted that inclusion of data from Qatar is necessary, and that seismic networks in Bahrain and the UAE are needed to complete regional coverage.

6. The committee feels strongly that an effort to equalize technical capacity and capabilities in the region is needed and assistance provided to those networks and observatories needing such assistance.

7. The committee feels that the preferred method of data exchange is through email and, when high bandwidth data is exchanged, such as waveforms that other protocols be used, such as FTP.

8. The committee recommends that the regional network be initiated in stages. The first stage would be done immediately, with exchange of parameter data through the internet. The data exchange would then be extended to exchange of seismograms for selected events. In the first stages, each observatory would be responsible for their own regional bulletin. In the next stage, a virtual center would be constructed which would include advanced computational capability, network processing and bulletin production. In the final and most ambitious stage, a network data 
center could be established that would receive all data from earthquakes in the region, produce a bulletin, and archive the data.

9. The committee strongly feels that an official sanction for regional seismic exchange is needed. The committee believes that the recommendation for regional seismic corporation be recognized as a result of the workshop and that a letter to this effect be sent to all home organizations.

10. The committee feels that it is important that the governments of each country is informed about the importance of seismic networks and the role that the national observatories perform.

11. Finally, the committee feels that an evaluation of facilities is needed and capabilities be assessed and to determine if training is required for all involved countries. 